\title{
Lactic acid bacteria: their applications in foods
}

\begin{abstract}
Lactic acid bacteria (LAB) are heterogenous group of bacteria which plays a significant role in a variety of fermentation processes. They ferment food carbohydrates and produce lactic acid as the main product of fermentation. In addition, degradation of proteins and lipids and production of various alcohols, aldehydes, acids, esters and sulphur compounds contribute to the specific flavour development in different fermented food products.

The main application of LAB is as starter cultures, with an enormous variety of fermented dairy (ie. cheese, yoghurt, fermented milks), meat, fish, fruit, vegetable and cereal products. Besides, they contribute to the flavour, texture and nutritional value of the fermented foods, and thus they are used as adjunct cultures. Acceleration of cheese maturation, enhancement of yoghurt texture with the production of exo polysaccharides and control of secondary fermentations in the production of wine are some examples. The production of bacteriocins and antifungal compounds has lead to the application of bio-protective cultures in certain foods. Moreover, the welldocumented health-promoting properties of certain LAB have lead to the addition of selected strains, in combination with bifidobacteria, as probiotic cultures with various applications in food industry.
\end{abstract}

Keywords: lactic acid bacteria, applications, fermented foods
Volume 6 Issue 2 - 2018

\author{
Bintsis T \\ Department of Agricultural Technology, TEl of West Macedonia, \\ Greece
}

Correspondence: Bintsis T, Department of Agricultural Technology, TEl of West Macedonia, 50100 Kozani, Greece, Tel +30694872 I720, Fax +30 246302 4995, Email tbintsis@gmail.com, bintsis@kastoria.teiwm.gr

Received: February 27, 2018| Published: March 15, 2018

\section{Introduction}

Lactic acid bacteria (LAB) play an important role in food, agricultural, and clinical applications. The general description of the bacteria included in the group is gram-positive, nonsporing, nonrespiring cocci or rods, which produce lactic acid as the major end product during the fermentation of carbohydrates. ${ }^{1}$ The common agreement is that there is a core group consisting of four genera; Lactobacillus, Leuconostoc, Pediococcus and Streptococcus. Recent taxonomic revisions have proposed several new genera and the remaining group now comprises the following: Aerococcus, Alloiococcus, Carnobacterium, Dolosigranulum, Enterococcus, Globicatella, Lactococcus, Oenococcus, Tetragenococcus, Vagococcus, and Weissella. ${ }^{2}$ Their importance is associated mainly with their safe metabolic activity while growing in foods utilising available sugar for the production of organic acids and other metabolites. Their common occurrence in foods along with their longlived uses contributes to their natural acceptance as GRAS (Generally Recognised as Safe) for human consumption. ${ }^{3}$ The EFSA's 'Panel on Biological Hazards (BIOHAZ)' has concluded that for the fermenting bacteria associated with food, whether resistant to antibiotics or not - with the possible exception of enterococci - there is no evidence for any clinical problem. ${ }^{4}$ However, they can act as a reservoir for transferable resistance genes. Strains with genes transferable in such a way could inter the food chain and increase the probability of a transfer to food associated intestinal pathogenic organisms.

The three main pathways which are involved in the manufacture and development of flavour in fermented food products are 1) glycolysis (fermentation of sugars), 2) lipolysis (degradation of fat) and 3) proteolysis (degradation of proteins). ${ }^{1,5-9}$ Lactate is the main product generated from the metabolism of carbohydrates and a fraction of the intermediate pyruvate can alternatively be converted to diacetyl, acetoin, acetaldehyde or acetic acid (some of which can be important for typical yogurt flavours). The contribution of LAB to lipolysis is relatively little, but proteolysis is the key biochemical pathway for the development of flavour in fermented foods. ${ }^{10,11}$ Degradation of such components can be further converted to various alcohols, aldehydes, acids, esters and sulphur compounds for specific flavour development in fermented food products. ${ }^{10,11}$

The genetics of the LAB have been reviewed ${ }^{12-18}$ and complete genome sequences of a great number of LAB have been published ${ }^{19}$ since 2001, when the first genome of LAB (Lactococcus lactis ssp. lactis IL1403) was sequenced and published. ${ }^{20}$

\section{Applications of LAB}

\section{Starter cultures for fermented foods}

Fermented foods are produced through fermentation of certain sugars by LAB and the origins of them are lost in antiquity. The most commonly LAB used as starter cultures in food fermentations are shown in Table 1. It is well-known that the greatest proportion of them belong to the category of dairy products, namely cheese, yoghurt, fermented milks, while fermented meat products, fish products, pickled vegetables and olives and a great variety of cereal products are manufactured, nowadays, using starter cultures. These products, were produced in the past through back slopping and the resulting product characteristics depended on the best-adapted strains dominance, whereas, the earliest productions of them were based on the spontaneous fermentation, resulting from the development of the microflora naturally present in the raw material and its environment. Today, the majority of fermented foods are manufactured with the addition of selected, well defined, starter cultures with well characterized traits, specific for each individual product. For a detailed classification of starter cultures see..$^{21-23}$ 
Table I Lactic acid bacteria used as starter cultures in the production of some fermented food products

\begin{tabular}{|c|c|c|}
\hline Product & Genera of LAB I & Reference \\
\hline \multicolumn{3}{|l|}{ Dairy products } \\
\hline \multirow[t]{4}{*}{ Cheese (Mesophilic starter) } & Lc. lactis ssp. lactis & 22 \\
\hline & Lc. lactis ssp. cremoris & \\
\hline & Lc. lactis ssp. lactis var. diacetylactis & \\
\hline & Leuc. mesenteroides ssp. cremoris & \\
\hline \multirow[t]{4}{*}{ Cheese (Thermophilic starter) } & S. thermoplillus & 22 \\
\hline & Lb. delbrueckii ssp. bulgaricus & \\
\hline & Lb. helveticus & \\
\hline & Lb. delbrueckii ssp. lactis & \\
\hline \multirow[t]{3}{*}{ Cheese (Mixed starter) } & Lc. lactis ssp. lactis & 22 \\
\hline & Lc. lactis ssp. cremoris & \\
\hline & S. thermoplillus & \\
\hline Yogurt & $\begin{array}{l}\text { Lb. delbrueckii ssp. bulgaricus, } \\
\text { S. thermophilus }\end{array}$ & 22 \\
\hline Fermented milks & $\begin{array}{l}\text { Lb. delbrueckii ssp. bulgaricus, S. thermophilus Lb. casei, } \\
\text { Lb. acidophilus, Lb. rhamnosus, Lb. johnsonii }\end{array}$ & 22 \\
\hline Yakult & Lb. casei ssp. casei & 22 \\
\hline Acidophilus milk & Lb. acidophilus & 22 \\
\hline Butter and buttermilk & $\begin{array}{l}\text { Lc. lactis ssp. lactis, Lc. lactis ssp. lactis var. diacetylactis, } \\
\text { Lc. lactis ssp. cremoris, Leuc. menesteroides ssp. cremoris }\end{array}$ & 22 \\
\hline Kefir & $\begin{array}{l}\text { Lb. kefir, Lb. kefiranofacies, Lb. brevis, Lb. plantarum, } \\
\text { Lb. paracasei spp. paracasei, Lc. lactis spp. lactis, } \\
\text { Leuc. mesenteroides }\end{array}$ & 62 \\
\hline Trahanas & $\begin{array}{l}\text { Lc. lactis ssp. lactis, Lc. lactis ssp. lactis var. diacetylactis, Leuc. menesteroides ssp. cremoris, Lb. } \\
\text { delbrueckii ssp. lactis, Lb. casei, } \\
\text { Lb. delbrueckii ssp. bulgaricus and Lb. Acidophilus }\end{array}$ & 63 \\
\hline \multicolumn{3}{|l|}{ Fermented meat products } \\
\hline Dry sausages & $\begin{array}{l}\text { Lb. sakei, Lb. curvatus, Lb. plantarum, Lb. pentosus, Lb. casei, } \\
\text { P. pentosaceous, P. acidilactici }\end{array}$ & 64,65 \\
\hline Salami Milano & Lb. sakei, Lb. plantarum & 66 \\
\hline Salame Piacentino & $\begin{array}{l}\text { Lb. acidophilus, } L b . \text { helveticus, } L b . \text { sakei, Lb. antri, Lb. oris, Lb. vaginalis, Lb. brevis, Lb. panis, } L b \text {. } \\
\text { versmoldensis, Lb. zeae, Lb. curvatus, Lb. paralimentarius, Lb. frumenti, Lb. plantarum, Lb. graminis, } \\
\text { Lb. reuteri }\end{array}$ & 67 \\
\hline Greek dry fermented sausages & $\begin{array}{l}\text { Lb. sakei, Lb. plantarum, Lb. curvatus, Lb. pentosus, Lc. } \\
\text { lactis ssp. lactis, W. hellenica, W. paramesenteroides, } \\
\text { W. viridescens, W. minor }\end{array}$ & 67 \\
\hline Chrorizo & $\begin{array}{l}\text { Lb. brevis, Lb. curvatus, Lb. sakei, Lc. lactis, P. acidilactici, } \\
\text { P. pentosaceus, Leuc. mesenteroides }\end{array}$ & 67 \\
\hline \multicolumn{3}{|l|}{ Fermented fish products } \\
\hline Thai fish & Lb. plantarum, Lb. reuteri & 68 \\
\hline \multicolumn{3}{|l|}{ Pickled fruits and vegetables } \\
\hline Cabbage (Sauerkraut) & $\begin{array}{l}\text { Leuc. mesenteroides, Lb. plantarum, Lb. brevis, } \\
\text { Lb. fermentum }\end{array}$ & 69 \\
\hline Cucumber & $\begin{array}{l}\text { Lb. brevis, Lb. plantarum, Lb. pentosus, Lb. acidophilus, } \\
\text { Lb. fermentum, Leuc. Mesenteroides }\end{array}$ & 70,71 \\
\hline Olives & Lb. brevis, Lb. plantarum, Lb. pentosus & 72,73 \\
\hline \multicolumn{3}{|l|}{ Fermented cereal products } \\
\hline \multirow[t]{2}{*}{ Sourdough } & Lb. brevis, Lb. hilgardii & 74,75 \\
\hline & $\begin{array}{l}\text { Lb. sanfransiscensis, Lb. farciminis, Lb. fermentum, } \\
\text { Lb. brevis, Lb. plantarum, Lb. amylovorus, Lb. reuteri, } \\
\text { Lb. pontis, Lb. panis, Lb. alimentarius, W. cibaria }\end{array}$ & \\
\hline Kimchi & $\begin{array}{l}\text { Leuc. mesenteroides, Lb. plantarum, W. kimchii sp. nov., } \\
\text { Lb. kimchi, Lb. sakei,W. koreensis }\end{array}$ & 76-78 \\
\hline Bushera & $\begin{array}{l}\text { Lb. plantarum, Lb. paracasei ssp. paracasei, Lb. fermentum, } \\
\text { Lb. brevis, Lb. delbrueckii ssp. delbrueckii, S. thermophilus }\end{array}$ & 79 \\
\hline Pozol & Leuc. mesenteroides, Lb. plantarum, Lb. confusus, Lc. lactis, Lc. raffinolactis & 80 \\
\hline
\end{tabular}

Lc. Lactococcus, Lb. Lactobacillus, Leuc. Leuconostoc, P. Pediococcus, S. Streptococcus, W. Weissella 


\section{Adjunct cultures}

Secondary cultures, or adjunct cultures or adjuncts, are defined as any cultures that are deliberately added at some point of the manufacture of fermented foods, but whose primary role is not acid production. Adjunct cultures are used in cheese manufacture to balance some of the biodiversity removed by pasteurisation, improved hygiene and the addition of defined-strain starter culture..$^{24,25}$ These are mainly non-starter LAB which have a significant impact on flavour and accelerate the maturation process. ${ }^{24,25}$

Extracellular polysaccharides (EPSs) are produced by a variety of bacteria and are present as capsular polysaccharides bound to the cell surface, or are released into the growth medium. ${ }^{26}$ These polymers play a major role in the production of yogurt, cheese, fermented cream and milk-based desserts ${ }^{27}$ where they contribute to texture, mouthfeel, taste perception and stability of the final products. In addition, it has been suggested that these EPSs or fermented milks containing these EPSs are active as prebiotics, ${ }^{28}$ cholesterol-lowering ${ }^{29}$ and immunomodulants. $^{30}$ EPS-producing strains of Streptococcus thermophilus and Lactobacillus delbreuckii ssp. bulgaricus have been shown to enhance the texture and viscosity of yogurt and to reduce syneresis. $^{31}$

For the production of wine, $\mathrm{LAB}$ are involved in the malolactic fermentation, that is a secondary fermentation, which involves the conversion of L-malate to L-lactate and $\mathrm{CO}_{2}$ via malate decarboxylase, also known as the malolactic enzyme, resulting in a reduction of wine acidity, providing microbiological stabilization and modifications of wine aroma. ${ }^{32,33}$

\section{Bio-protective cultures}

Certain LAB have been found to produce bacteriocins, namely, polypeptides synthesized ribosomally by bacteria that can have a bacteriocidal or bacteriostatic effect on other bacteria. ${ }^{34,35}$ In general, bacteriocins lead to cell death by inhibiting cell wall biosynthesis or by disrupting the membrane through pore formation..$^{36}$ Bacteriocins are therefore important in food fermentations where they can prevent food spoilage or the inhibition of food pathogens. The best known bacteriocin is nisin, which has gained widespread application in the food industry and is used as a food additive in at least 50 countries, particularly in processed cheese, dairy products and canned foods. ${ }^{37}$ Examples of useful bacteriocins produced by LAB are lacticin $3147^{38-41}$ from lactococci, macedovicin from Streptococcus macedonicus ACA-DC $198,{ }^{42,43}$ reuterin from Lactobacillus reuteri, ${ }^{44}$ sakacin M from Lactobacillus sake $148^{45}$ curvacin A, curvaticin L442 and lactocin AL705 from Lactobacillus curvatus LTH1174, ${ }^{46}$ pediocin PA-1/AcH from Pediococcus acidilactici, ${ }^{47}$ plantaricins (A, EF and JK) from Lactobacillus plantarum. ${ }^{47}$ The above bacteriocins have proved effective in many food systems for the control of food spoilage or pathogenic bacteria.

Antifungal activities of LAB have been reported. ${ }^{48-50}$ In addition; LAB strains also have the ability to reduce fungal mycotoxins, either by producing anti-mycotoxinogenic metabolites, or by absorbing them. ${ }^{50}$

For LAB to be used as bio-protective starter cultures, they must possess a range of physical and biochemical characteristics, and most importantly, the ability to achieve growth and sufficient production of antimicrobial metabolites, which must be demonstrated in the specific food environment. ${ }^{48}$

\section{Probiotic cultures}

LAB are considered as a major group of probiotic bacteria; ${ }^{51,52}$ probiotic has been defined by Fuller $^{53}$ as "a live microbial feed supplement which beneficially affects the host animal by improving its intestinal microbial balance". Salminen et al. ${ }^{54}$ proposed that probiotics are microbial cell preparations or components of microbial cells that have a beneficial effect on the health and well-being of the host. Commercial cultures used in food applications include mainly strains of Lactobacillus spp., Bifidobacterium spp. and Propionibacterium spp. Lactobacillus acidophilus, Lactobacillus casei, Lb. reuteri, Lactobacillus rhamnosus and Lb. plantarum are the most used LAB in functional foods containing probiotics. ${ }^{55,56}$ Argentinean Fresco cheese,$^{57} \mathrm{Cheddar}^{58}$ and Gouda ${ }^{59}$ are some examples of applications of probiotic $\mathrm{LAB}$, in combination with bifidobacteria, in cheeses.

The health-promoting effects of LAB are shown in Table 2 . Apparently, these effects are species and strain specific, and the big challenge is the use of probiotic cultures composed of multiple species ${ }^{60}$ In addition, LAB, as part of gut microbiota ferment various substrates such as biogenic amines and allergenic compounds into short-chain fatty acids and other organic acids and gases. ${ }^{61}$

Table 2 Effects of probiotics on the human health

\begin{tabular}{ll}
\hline Probiotic effect & Reference \\
\hline Assimilation of cholesterol & 79,80 \\
Lactose intolerance & $79-81$ \\
$\begin{array}{l}\text { Control viral, bacterial and antibiotic associated diarrheal } \\
\text { diseases }\end{array}$ & $79,80,83-85$ \\
Inflammatory bowel disease & 79 \\
Allergies and atopic dermatitis & 86,87 \\
Colonic carcinogens & 88,89 \\
Control of pathogenic bacteria & 91,92 \\
$\begin{array}{l}\text { Stimulation of the immune system on the gut mucosal } \\
\text { surface }\end{array}$ & 93 \\
\hline
\end{tabular}

In recent years, the genomes of several probiotic species have been sequenced, thus paving the way to the application of 'omics' technologies to the investigation of probiotic activities. ${ }^{60}$ Moreover, although recombinant probiotics have been constructed, the industrial application of genetically engineered bacteria is still hampered by legal issues and by a rather negative general public opinion in the food sector. ${ }^{60}$

\section{Conclusion}

LAB are the most commonly used microorganisms for the fermentation and preservation of foods. Their importance is associated mainly with their safe metabolic activity while growing in foods utilising available sugar for the production of organic acids and other metabolites.

Advances in the genetics, molecular biology, physiology, and biochemistry of LAB have provided new insights and applications for these bacteria. Bacterial cultures with specific traits have been developed during the last 17 years, since the discovery of the complete genome sequence of Lc. lactis ssp. lactis IL1403 and a variety of commercial starter, functional, bio-protective and probiotic cultures with desirable properties have marketed.

However, the great challenge for food industry is to produce 
multiple strain cultures with multiple functions for specific products from specific regions of the world. Also it is a challenge to produce foods, which are similar in sensory characteristics and nutritional value to the traditional products, even with special health-promoting properties, in a standardized, safe and controlled process.

\section{Acknowledgements}

None.

\section{Conflict of interest}

Author declares no conflicts of interest in this paper.

\section{References}

1. Hayek SA, Ibrahim SA. Current limitations and challenges with lactic acid bacteria: a review. Food and Nutrition Sciences. 2013;4:73-87.

2. Khalid K. An overview of lactic acid bacteria. Intern $J$ Bioscien. 2011;1(3):1-13

3. Bourdichon F, Berger B, Casaregola S, et al. A Safety assessment of microbial food cultures with history of use in fermented dairy products. Bullet IDF. 2012;455:2-12.

4. EFSA. Scientific opinion of the panel on biological hazards on the request from EFSA on the maintenance of the list of QPS microorganisms intentionally added to food or feed. EFSA J. 2008;928:1-48.

5. Wedajo B. Lactic acid bacteria: benefits, selection criteria and probiotic potential in fermented food. J Prob Health. 2015;3:129.

6. Grattepanche F, Miescher-Schwenninger S, Meile L, et al. Recent developments in cheese cultures with protective and probiotic functionalities. Dairy Sci Technol. 2008;88(4-5):421-444.

7. Law BA. Cheese ripening and cheese flavour technology. In: Law BA, editor, Technology of cheese making, Sheffield Academic Press Ltd., Sheffield, UK, 1999;163-192.

8. Smit G, Smit BA, Engels WJ. Flavour formation by lactic acid bacteria and biochemical flavour profiling of cheese products. FEMS Microbiol Rev. 2005;29(3):591-610.

9. Tamime AY, Robinson RK. Yoghurt Science and Technology. 2nd ed. Woodhead Publishing Ltd. Cambridge; 1999.

10. Ammor MS, Mayo B. Selection criteria for lactic acid bacteria to be used as functional starter cultures in dry sausage production: An update. Meat Science.2006;76(1):138-146.

11. Souza MJ, Ardo Y, McSweeney PLH. Advances in the study of proteolysis in cheese. Int Dairy J. 2001;11(4):327-345.

12. Broadbent JR, McMahon, DJ, Welker DL, et al. Biochemistry, genetics, and applications of exopolysaccharide production in Streptococcus thermophilus: a review. J Dairy Sci. 2003;86(2):407-423.

13. Callanan MJ, Ross RP. Starter cultures: genetics. In: Fox PF, McSweeney PLH, Cogan TM, editors. Cheese: Chemistry, physics and microbiology. 4th ed. Elsevier Academic Press, London, UK, 2004; 149-161.

14. Klaenhammer T, Altermann E, Arigoni F, et al. Discovering lactic acid bacteria by genomics. Antonie van Leeuwenhoek. 2002; 82(1-4):29-58.

15. Morelli L, Vogensen FK, Von Wright A. Genetics of lactic acid bacteria In: Salminen S, von Wright A, Ouwehand A, editors. Lactic acid bacteria - microbiological and functional aspects, 3rd ed. Marcel Dekker Inc., New York, 2011; 249-293.

16. Mills S, O'Sullivan O, Hill C, et al. The changing face of dairy starter culture research: From genomics to economics. Intern J Dairy Tech. 2010;63:149-170.
17. Castillo Martinez FA, Balciunas EM, Salgado JM et al. Lactic acid properties, applications and production: A review. Trends Food Sci \& Tech. 2013;30(1):70-83.

18. Zhu Y, Zhang Y, Li Y. Understanding the industrial application potential of lactic acid bacteria through genomics. Appl Microbiol Biotechnol. 2009;83(4):597-610.

19. https://www.ncbi.nlm.nih.gov/genome/browse

20. Bolotin A, Wincker P, Mauger S, et al. The complete genome sequence of the lactic acid bacterium Lactococcus lactis ssp. lactis IL1403. Genome Res. 2001;11(5):731-753.

21. Bintsis T, Athanasoulas A. Dairy starter cultures. In: Papademas P, editor. Dairy microbiology, a practical approach, CRC Press, Boca Raton, FL, 2015; 114-154

22. Tamime AY. Microbiology of starter cultures. In: Robinson RK, editor. Dairy microbiology handbook, 3rd ed. John Wiley \& Sons Inc, New York, 2002; 261-366.

23. Parente E, Cogan TM. Starter cultures: general aspects. In: Fox PF, McSweeney PLH, Cogan TM, editors. Cheese: Chemistry, physics and microbiology, 4th ed. Elsevier Academic Press, London, UK, 2004: 123-147.

24. Rattanachaikunsopon P, Phumkhachorn P. Lactic acid bacteria: their antimicrobial compounds and their uses in food production. Annals of Biol Res. 2010;1(4):218-228.

25. Cogan TM, Beresford TP, Steele J, et al. Invited review: advances in starter cultures and cultured foods. J Dairy Scien. 2007;90(9):40054021.

26. Jolly L, Vincent SJ, Duboc P, et al. Exploiting expoly saccharides from lactic acid bacteria. Antonie van Leeuwenhoek. 2002;82(1-4):367-374.

27. Gibson GR, Robertfroid MB. Dietary modulation of the human colonic microbiota: introducing the concept of prebiotics. $J$ Nutr. 1995;125(6):1401-1412

28. Nakajima H, Suzuki Y, Kaizu H, et al. Cholesterol-lowering activity of ropy fermented milk. J Food Scien. 1992;57:1327-1329.

29. Hosono A, Lee J, Ametani A, et al. Characterization of a watersoluble polysaccharide fraction with immunopotentiating activity from Bifidobacterium adolescentis M101-4. Biosc Biotechn Biochem. 1997;61(2):312-316.

30. Hassan AN, Ipsen R, Janzen T, et al. Microstructure and rheology of yogurt made with cultures differing only in their ability to produce exopolysaccharides. J Dairy Scien. 2003;86(5):1632-1638.

31. Doleyres Y, Schaub L, Lacroix C. Comparison of the functionality of exopolysaccharides produced in situ or added as bioingredients on yogurt properties. J Dairy Scien. 2005;88(12):4146-4156.

32. Liu SQ. A review: malolactic fermentation in wine beyond deacidification. J Appl Microbiol. 2002;92(4):589-601.

33. Cappelo MS, Zapparoli G, Logrieco A, et al. Linking wine lactic acid bacteria diversity with wine aroma and flavour. Int J Food Microb. 2017;43:16-27.

34. McAuliffe O, Ross RP, Hill C. Lantibiotics: structure, biosynthesis and mode of action. FEMS Microbiol Rev. 2001;25(3):285-308.

35. Ross RP, Morgan S, Hill C. Preservation and fermentation: past, present and future. Intern J Food Microb. 2002;79(1-2):3-16.

36. Twomey D, Ross RP, Ryan M et al. Lantibiotics produced by lactic acid bacteria: structure, function and applications. Antonie Van Leeuwenhoek. 2002;82(1-4):165-185. 
37. Delves-Broughton J, Blackburn P, Evans RJ, et al. Applications of the bacteriocin, nisin. Antonie Van Leeuwenhoek. 1996;69(2): 193-202.

38. Ryan MP, Rea MC, Hill C, et al. An application in cheddar cheese manufacture for a strain of Lactococcus lactis producing a novel broad-spectrum bacteriocin, lacticin 3147. Applied Environ Microb. 1996;62(2):612-619.

39. Coakley M, Fitzgerald G, Ross RP. Application and evaluation of the phage resistance- and bacteriocin encoding plasmid pMRC01 for the improvement of dairy starter cultures. Applied Environ Microb. 1997;63:1434-1440.

40. Morgan SM, Galvin M, Ross RP, et al. Evaluation of a spray-dried lacticin 3147 powder for the control of Listeria monocytogenes and Bacillus cereus in a range of food systems. Letters Applied Microb. 2001;33(5):387-391.

41. O'Sullivan L, O'Connor EB, Ross RP, et al. Evaluation of live-cultureproducing lacticin 3147 as a treatment for the control of Listeria monocytogenes on the surface of smear-ripened cheese. $J$ Applied Microb. 2006;100(1):125-143.

42. Georgalaki MD, Van Den Berghe E, Kritikos D, et al. Macedocin, a food-grade lantibiotic produced by Streptococcus macedonicus ACADC 198. Appl Environ Microbiol. 2002;68(12):5891-5903.

43. Georgalaki MD, Papadimitriou K, Anastasiou R, et al. Macedovicin, the second food-grade lantibiotic produced by Streptococcus macedonicus ACA-DC 198. Food Microb. 2013;33(1):124-130.

44. Rodríguez E, Arqués JL, Rodríguez R, et al. Reuterin production by lactobacilli isolated from pig faeces and evaluation of probiotic traits. Lett Appl Microbiol. 2003;37(3):259-263.

45. Parada JL, Caron CR, Medeiros ABP. Bacteriocins from lactic acid bacteria: purification, properties and use as biopreservatives. Brazilian Arch Biology Techn. 2007;50(3):521-542.

46. Castellano P, Vignolo G. Inhibition of Listeria innocua and Brochothrix thermosphacta in vacuum-packaged meat by addition of bacteriocinogenic Lactobacillus curvatus CRL705 and its bacteriocins. Letters in Applied Microb. 2006;43(2):194-199.

47. Castellano P, Belfiore $\mathrm{C}$, Fadda $\mathrm{S}$ et al. A review of bacteriocinogenic lactic acid bacteria used as bioprotective cultures in fresh meat produced in Argentina. Meat Scien. 2008;79(3):483-499.

48. Cheong EYL, Sandhu A, Jayabalan J, et al. Isolation of lactic acid bacteria with antifungal activity against the common cheese spoilage mould Penicillium commune and their potential as biopreservatives in cheese. Food Control. 2014;46:91-97.

49. Crowley S, Mahony J, van Sinderen D. Current perspectives on antifungal lactic acid bacteria as natural bio-preservatives. Trends Food Scien \& Techn. 2013;33(2):93-109.

50. Dalié DKD, Deschamps AM, Richard-Forget F. Lactic acid bacteria Potential for control of mould growth and mycotoxins: A review. Food Control. 2010;21(4):370-380.

51. Collins JK, Thornton G, Sullivan GO. Selection of probiotic strains for human applications. Int Dairy J. 1998;8(5-6)487-490.

52. Tannock GW. Probiotics: A critical review. Horizon Scientific Press, Wymondham, UK; 1999.

53. Fuller R. A review: Probiotics in man and animals. J Appl Bact 1989;66(5):365-378.

54. Salminen S, Ouwehand A, Benno Y, et al. Probiotics: how should they be defined? Trends Food Sci Techn. 1999;10(3):107-110.

55. Champagne C, Gardner N, Roy D. Challenges in the addition of probiotic cultures to foods. Crit Rev Food Sci Nutr. 2005;45(1): 61-84.
56. Champagne CP, Møllgaard H. Production of probiotic cultures and their addition in fermented foods. In: Farnworth ER, editor. Handbook of fermented functional foods, 2nd ed. CRC Press, Boca Raton, FL, US, 2008; 513-532.

57. Vinderola CG, Prosello W, Ghiberto D, et al. Viability of probiotic (Bifidobacterium, Lactobacillus acidophilus and Lactobacillus casei) and nonprobiotic microflora in Argentinean Fresco Cheese. J Dairy Sci. 2000;83(9):1905-1911.

58. Gardiner G, Ross RP, Collins JK, et al. Development of a probiotic Cheddar cheese containing human derived Lactobacillus paracasei strains. Appl Envir Microb. 1998;64(6):2192-2199.

59. Gomes AMP, Malcata FX, Klaver FAM, et al. Incorporation and survival of Bifidobacterium sp. strain Bo and Lactobacillus acidophilus strain Ki in a cheese product. Neth Milk \& Dairy J. 1995;49:71-95.

60. Foligné B, Daniel C, Pot B. Probiotics from research to market: the possibilities, risks and challenges. Curr Opin Microb. 2013;16(3):284 292.

61. Gibson GR, Fuller R. Aspects of in vitro and in vivo research approaches directed toward identifying probiotics and prebiotics for human use. $J$ Nutr. 2000;130:391-395

62. Kıvanç M, Yapıcı E. Kefir as a probiotic dairy beverage: determination lactic acid bacteria and yeast. Intern J Food Engin. 2015;1(1):55-60.

63. Lazos ES, Aggelousis G, Bratakos M. The fermentation of trahanas: a milk-wheat flour combination. Plant Foods Human Nutr. 2015;44(1):4562 .

64. Hammes WP, Hertel C. New developments in meat starter cultures. Meat Sci. 1998;49:25-38.

65. Hugas M, Monfort JM. Bacterial starter cultures for meat fermentation. Food Chem. 1997;59(4):547-554.

66. Aquilanti L, Garofalo C, Osimani A, et al. Ecology of lactic acid bacteria and coagulase negative cocci in fermented dry sausages manufactured in Italy and other Mediterranean countries: an overview. Int Food Res J. 2016;23(2):429-445.

67. Saithong P, Panthavee W, Boonyaratanakornkit M, et al. Use of a starter culture of lactic acid bacteria in plaasom, a Thai fermented fish. $J$ BiosC Bioengin. 2010;110(5):553-557.

68. Pundir RK, Jain P. Change in microflora of sauerkraut during fermentation and storage. World J Dairy \& Food Sci. 2010;5(2): 221-225.

69. Wakil SM, Lada SA, Fasika SA. Isolation and identification of antimicrobial-producing lactic acid bacteria from fermented cucumber. African J Biotech. 2014;13(25):2556-2564.

70. Nilchian Z, Sharifan A, Rahimi E, et al. Improvement of fermented cucumber characteristics by starter culture of lactobacillus plantarum, $L$. bulgaricus and S. thermophiles. J Food Biosc Techn. 2016;6(2):31-40.

71. Con AH, Karasli N. Determination of antagonistic starter cultures for pickle and olive fermentation processes. Czech J Food Sci. 2009;27(3):185-193.

72. Hurtado A, Reguant C, Bordons A, et al. Lactic acid bacteria from fermented table olives. Food Microb. 2012;31(1):1-8.

73. Vollmor A, Meuser F. Influence of starter cultures consisting of lactic acid bacteria and yeasts on the performance of a continuous sourdough fermenter. Cereal Chem. 1992;69(1):20-27.

74. Palla M, Cristani C, Giovanneti $M$, et al. Identification and characterization of lactic acid bacteria and yeasts of PDO Tuscan bread sourdough by culture dependent and independent methods. Intern $J$ Food Microb. 2017;250:19-26. 
75. Mheen TI, Kwon TW. Effect of temperature and salt concentration on kimchi fermentation. Kor J Food Sci Technol. 1984;16: 443-450.

76. Choi HJ, Cheigh CI, Kim SB, et al. Weissella kimchii sp. nov., a nove lactic acid bacterium from kimchi. Intern J of System and Evolut Microb. 2002;52(Pt 2):507-511.

77. Lee KB, Kim HJ, Lee EJ. Mixed cultures of Kimchi lactic acid bacteria show increased cell density and lactate productivity. African J Biotech. 2013;12(25):4000-4005.

78. Muyanja CMBK, Narvhus JA, Treimo J, et al. Isolation, characterisation and identification of lactic acid bacteria from bushera: a Ugandan traditional fermented beverage. Intern J Food Microb. 2003;80(3):201210 .

79. Nuraida L, Wacher MC, Owens JD. Microbiology of pozol, a Mexican fermented maize dough. World J Microb \& Biotech. 1995;11(5):567571.

80. Florou-Paneri P, Christaki E, Bonos E. Lactic acid bacteria as source of functional ingredients. In: Kongo M, editor. Lactic acid bacteria - R\&D for food, health and livestock purposes, Intechopen, Rijeka, Croatia, 2013; 589-614.

81. Pereira DIA, Gibson GR. Cholesterol assimilation by lactic acid bacteria and bifidobacteria isolated from the human gut. Appl Environ Microb. 2002;68(9):4689-4693.

82. Heyman M. Effect of lactic acid bacteria on diarrheal diseases. $J A m$ Coll Nutr. 2000;19(Suppl 2):137-146.

83. Hove H, Nørgaard H, Brøbech Mortensen P. Lactic acid bacteria and the human gastrointestinal tract. Eur J Clin Nutr. 1999;53(5):339-350.

84. Ehrmann MA, Kurzak P, Bauer J, et al. Characterization of lactobacilli towards their use as probiotic adjuncts in poultry. $J$ Appl Microb. 2002;92(5):966-975.

85. Majamaa H, Isolauri E. Probiotics: A novel approach in the management of food allergy. J Allergy Clin Immunol. 1997;99(2):179-185.

86. Oksanen PJ, Salminen S, Saxelin M, et al. Prevention of travellers' diarrhea by Lactobacillus GG. Ann Med. 1990;22(1):53-56.

87. Cross ML. Microbes versus microbes: immune signals generated by probiotic lactobacilli and their role in protection against microbial pathogens. FEMS Immunol Med Microb. 2002;34(4):245-253.

88. Isolauri E, Arvola T, Sütas Y, et al. Probiotics in the management of atopic eczema. Clin Exp Allerg. 2000;30(11):1604-1610.

89. Hirayama K, Rafter J. Review: The role of probiotic bacteria in cancer prevention. Micrones Infect. 2000;2(6):681-686.

90. Rolfe RD. The role of probiotic cultures in the control of gastrointestinal health. J Nutr. 2000;130:396-402.

91. Sanders ME. Overview of functional foods: emphasis on probiotic bacteria. Int Dairy J. 1998;8(5-6):341-347.

92. O’Sullivan L, Ross RP, Hill C. Review: Potential of bacteriocinproducing lactic acid bacteria for improvements in food safety and quality. Biochim. 2002;84(5-6):593-604.

93. Elliason DJ, Tatini SR. Enhanced inactivation of Salmonella typhimurium and verotoxigenic Escherichia coli by nisin at $6.5^{\circ} \mathrm{C}$. Food Microb. 1999;16(10):257-267.

94. Edelman S, Westerlund-Wikström B, Leskelä S, et al. In vitro adhesion specifity of indigenous lactobacilli within the avian intestinal tract. Appl Environ Microb. 2002;68(10):5155-5159. 